\title{
Presentación de la Ética eudemia de Aristóteles, en traducción de Antonio Gómez Robledo
}

\author{
Mauricio Beuchot
}

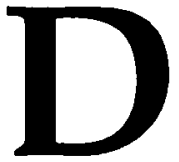

on Antonio Gómez Robledo me hizo volver la vista hacia el tratamiento que hace Aristóteles de la felicidad en su Etica eudemia. Seguiré su consejo, como un homenaje y prueba de amistad. Es, en verdad, un tratado muy hermoso. La ética de Aristóteles ha sido caracterizada como eudaimonística, esto es, una ética centrada en, o polarizada por, la felicidad. La felicidad es lo que mueve al hombre, lo que lo hace actuar, aquello que constituye el fin último de la vida humana $y$, por tanto, de todas sus acciones. "La felicidad -dice Aristóteles-es lo más bello, lo mejor y lo más placentero de todas las cosas". ${ }^{1}$ Káliston, áriston, hedistón: con esas palabras tan fuertes quiere expresar el Estagirita todo lo que es la felicidad.

Pero la felicidad como ideal de la ética se parece a esas expresiones formales que a veces se hallan en la ética kantiana; falta darles un contenido material; pues, así como están, pueden ser llenadas con cualquier cosa, cada uno puede entender como felicidad una cosa distinta, y con ello la felicidad no sirve de mucho para guiar en la moralidad. Por ello Aristóteles pasa a preguntarse qué es en verdad la felicidad. Y lo primero que indaga es si la felicidad es algo que se tiene por naturaleza o se adquiere, por ejemplo con el aprendizaje.

Evidentemente -como lo vemos con pesar- los hombres no tienen la felicidad por naturaleza, y han de afanarse en conseguirla. Ella es la que resulta del vivir bien. En efecto, el vivir bien tiene un fin, en el cual consiste la felicidad. Y, así, todo el que puede vivir según su voluntad, a saber, el que es libre, trata de vivir bien, y para ese vivir bien se propone un fin. Además de ser vida buena es vida bella; es una vida que satisface la esperanza de los

'Aristóteles, Etica eudemia, trad. Antonio Gómez Robledo, México, UNAM, (Bibliotheca Scriptorum Graecorum et Romanorum Mexicana), 1994, p. 1. 
hombres honestos. Pero algo nos deja todavía insatisfechos: la vida buena sigue siendo algo todavía formal: puede ser muchas cosas. El propio Estagirita habla de tres tipos principales de vida que se considera buena, según criterios muy diversos: la vida política, la vida filosófica y la vida de placer. Y añade Aristóteles, en traducción de don Antonio:

De estas tres, la vida filosófica está cifrada en la sabiduría y en la contemplación de la verdad; la vida política en las bellas acciones, entendiendo por tales las que provienen de la virtud, y la vida hedonística son los placeres del cuerpo. ${ }^{2}$

Gómez Robledo traduce aquí "frónesis" por "sabiduría", lo cual no deja de llamar la atención; tal vez le da un uso demasiado amplio, o tal vez se ha querido referir a una parte de la sabiduría, que es el saber práctico, de la prudencia. Pues, al parecer, Aristóteles quiere resaltar los dos aspectos de esa sabiduría en general, el teórico: theoría, y el práctico: frónesis, ambos constitutivos de la vida filosófica. Aquí creemos que es un tanto discutible la traducción de Gómez Robledo, pero resulta aceptable si se entiende la frónesis, más que como eufrosine o propiamente prudencia, como un saber más amplio que el puramente práctico.

Gómez Robledo alcanza traducciones muy logradas y bellas, como cuando Aristóteles dice que cada persona encontrará como vida buena una de esas tres, y así tendrá como ideal o como preferencia al sibarita Sardanápalo, o a un sabio político, o a un filósofo, como Anaxágoras, de quien se cuenta que, preguntado "por qué era preferible la existencia a la nada, respondió: 'Por contemplar el cielo y el orden del universo'. Pensaba, pues, que la preferencia de la vida era algo valioso por la adquisición de cierta ciencia". ${ }^{3}$

Es aquí donde el de Estagira aprovecha para anticipar y sugerir que la vida filosófica es la auténticamente buena, a saber, es la mejor, es la vida feliz. Pues todo hombre tiene cierta tendencia a la verdad. Esto se ve en que desea los argumentos más conducentes a ella, y éstos son los argumentos filosóficos. Y lo son los que van de lo verdadero a lo verdadero, y no los que van de lo falso a lo verdadero, esto es, con implicación material, la cual se considera como posible en los Anatíticos Priores, ${ }^{4}$ donde el ejemplo que pone Aristóteles es el siguiente silogismo (al parecer expositivo o cuantificado individualmente): "Un hombre es una piedra, una piedra es un animal; por consiguiente, un hombre es un animal".

${ }^{2}$ Ibid., p. 6.

${ }^{3}$ Ibid., p. 8.

${ }^{4} \mathrm{Cf}$. Aristóteles, Analíticos Priores, II, 2, 53b7 ss.

'I Ibid., p. 12 y p. XXXv, nota 10. 
Hay que buscar, por el contrario, la verdad con la verdad, porque sólo con premisas verdaderas y causales se podrá probar. $\mathrm{Y}$, así, hay que buscar claramente qué es la felicidad, para poder probar con ella lo que conduce a la vida moral. De entre los bienes, unos son practicables por el hombre, esto es, puede proponérselos como fines de su acción, y otros no son practicables, por pertenecer a cosas inmóviles.

$\mathrm{Y}$ así ponemos entre las cosas practicables tanto la salud y la rique. za como las cosas que hacemos en vista de aquéllas, como las actividades higiénicas y las lucrativas. Resulta claro, en suma, que la felicidad debe postularse como la cosa más excelente de entre las practicables por el hombre. ${ }^{6}$

Todo esto podemos reconocérselo a Aristóteles. Pero seguimos sin saber cuál es la vida buena, que lleva a la felicidad. Y el Filósofo aborda entonces la noción de bien en sí mismo. Aquí se acuerda de lo que ya ha dicho en la Metafísica, en el libro V, que el bien se predica en muchos sentidos, tantos como el ente. Y lo que nos queda como definición del bien es que es aquello que todos tienen por tal. Aquí recordamos que para Aristóteles, cuando no hay consenso total, se va al consenso de la mayoría, y cuando no lo hay, se va al de los sabios. Pero, ¿quiénes son los sabios? ¿Quiénes pueden en verdad llamarse tales?

Sólo podemos partir de la opinión de nuestros semejantes, del consenso sobre lo opinable. Y de ahí pasar a la afirmación del bien, lo más universal que se pueda. Es el tremendo problema de la universalización en moral.

Aristóteles, en la Ética nicomáquea, discernirá tres grandes clases de bienes: el bien útil, el bien deleitable y el bien honesto. El primero es el más deleznable, es el que menos tiene carácter de fin, y tiene más carácter de medio. En cambio, el último sí puede ser fin en sí mismo. Y esto se ve ya en la Etica eudemia: el bien honesto es el mayor bien. Hemos dicho que el bien es practicable o no practicable por el hombre. El Estagirita concluye algo ya de este recorrido:

Es manifiesto, en conclusión, que el bien en sí que buscamos no es ni la idea del bien, ni tampoco el bien común, ya que la primera es inmóvil y no practicable, y lo segundo es móvil pero no practica. ble. Mas aquello por lo cual obramos es en tanto que fin el bien supremo y causa de los demás bienes que le están subordinados y

${ }^{6}$ Aristóteles, Etica eudemia, p. 13. 
el primero de todos, por lo que puede decirse que es éste el bien en sí y el fin último de todos los actos humanos. Y este bien entra bajo la consideración de la ciencia soberana entre todas, que comprende la política, la económica y la sabiduría. ${ }^{7}$

En este punto, también es discutible la traducción de Gómez Robledo. Aristóteles dice, literalmente, que entre los múltiples sentidos de "bien" se halla el de "bello", un bien bello, o como decía ya Platón, un bien bello de ver. Pero Gómez Robledo traduce, uniéndolos con un guión, "lo bello-honesto". Ciertamente para el Estagirita el bien honesto es el bien más bello y el mejor candidato para ocupar ese lugar. Pero nos deja un poco la duda de si se está refiriendo aquí al bien honesto que será tan importante en la Ética nicomáquea y ya también aquí en la Etica eudemia. Ese bien es el que caracterizará como buena la amistad (según lo hizo ver en el lib. VIII de la Etica nicomáquea), es decir, la amistad, al igual que el bien, puede ser útil, deleitable y honesta. Pero la amistad por la utilidad es la más deleznable y no llega a amistad, es utilización de las personas. La amistad por el deleite es todavía imperfecta; ya no se trata de utilidad, pero la supera en poco. En cambio, la amistad honesta es en la que se busca el bien del amigo, más allá de la utilidad y el deleite o alegría que pueda uno obtener en el amigo; es una amistad por la virtud y, aunque no parezca beneficiarnos, nos da el mayor bien.

Tal vez con lo que nos ofrece aquí Aristóteles no ha llegado uno a tener una definición muy substanciosa de la felicidad, y algunos hasta no la acepten como guía de la moralidad; pero nos ha brindado algo inapreciable: la enseñanza de que lo que mejor conduce a la felicidad (cifrada en la contemplación) es la amistad buena, la honesta, que es dialogante, que hace a los amigos buscar entre todos la virtud. Y encuentro que ésa fue la amistad que yo tuve con don Antonio Gómez Robledo.

'Ibid., p. 17. 